Supporting information for

\title{
Recent advances in understanding the micro- and nanoscale phenomena of amorphous solid dispersions
}

\author{
Ralm G. Ricarte, ${ }^{\epsilon}$ Nicholas J. Van Zee, ${ }^{\dagger}$ Ziang Li,${ }^{\ddagger}$ Lindsay M. Johnson,${ }^{\dagger}$ Timothy P. Lodge,,${ }^{* \dagger, \dagger}$ \\ and Marc A. Hillmyer ${ }^{*}$, \\ ${ }^{\epsilon}$ Molecular, Macromolecular Chemistry, and Materials Laboratory, CNRS, ESPCI-Paris, PSL \\ Research University, 10 Rue Vauquelin, 75005 Paris, France, 'Department of Chemistry, and \\ Department of Chemical Engineering and Materials Science, University of Minnesota, \\ Minneapolis, 55455-0431, United States
}

Email: lodge@umn.edu and hillmyer@umn.edu

\section{Comparison of amorphous solid dispersion characterization techniques}

Table S1 compares the utilities, advantages, and disadvantages of various spectroscopy and microscopy techniques for characterizing amorphous solid dispersions. 
Table S1. Comparison of amorphous solid dispersion characterization techniques

\begin{tabular}{|c|c|c|c|c|c|c|c|}
\hline Technique & \multicolumn{4}{|c|}{ Utilities $^{\#}$} & \multirow[t]{2}{*}{ Advantages } & \multirow[t]{2}{*}{ Disadvantages } & \multirow[t]{2}{*}{ References } \\
\hline & CRY & PS & I & $\mathbf{M}$ & & & \\
\hline $\begin{array}{c}\text { Infrared } \\
\text { spectroscopy }\end{array}$ & $\checkmark$ & - & $\checkmark$ & - & $\begin{array}{l}\text { - Quantifies } \\
\text { crystallinity } \\
\text { - Enables in-line } \\
\text { process monitoring }\end{array}$ & $\begin{array}{l}\text { - Insensitive to weak } \\
\text { vibrations } \\
\text { - Difficult to carry } \\
\text { out in water }\end{array}$ & $\begin{array}{l}\text { S1, S2, S3, } \\
\text { S4, S5, S6, } \\
\text { S7, S8 }\end{array}$ \\
\hline $\begin{array}{c}\text { Raman } \\
\text { spectroscopy }\end{array}$ & $\checkmark$ & - & $\checkmark$ & - & $\begin{array}{l}\text { - Quantifies } \\
\text { crystallinity } \\
\text { - Enables in-line } \\
\text { process monitoring }\end{array}$ & $\begin{array}{l}\text { - Low signal-to- } \\
\text { noise ratio }\end{array}$ & $\begin{array}{l}\text { S1, S5, S6, } \\
\text { S7, S9 }\end{array}$ \\
\hline $\begin{array}{l}\text { Solid-state } \\
\text { nuclear } \\
\text { magnetic } \\
\text { resonance } \\
\text { spectroscopy }\end{array}$ & - & $\checkmark$ & $\checkmark$ & - & $\begin{array}{l}\text { - Identifies domains } \\
\text { as small as } 5 \mathrm{~nm} \text { in } \\
\text { size }\end{array}$ & $\begin{array}{l}\text { - Requires long } \\
\text { measurement times }\end{array}$ & $\begin{array}{l}\text { S10, S11, } \\
\text { S12, S13, } \\
\text { S14 }\end{array}$ \\
\hline $\begin{array}{c}\text { Dielectric } \\
\text { spectroscopy }\end{array}$ & $\checkmark$ & $\checkmark$ & - & $\checkmark$ & $\begin{array}{l}\text { - Superior sensitivity } \\
\text { than DSC }\end{array}$ & $\begin{array}{l}\text { - Data interpretation } \\
\text { is non-trivial }\end{array}$ & $\begin{array}{l}\text { S15, S16, } \\
\text { S17, S18, } \\
\text { S19 }\end{array}$ \\
\hline $\begin{array}{l}\text { Transmission } \\
\text { electron } \\
\text { microscopy }\end{array}$ & $\checkmark$ & $\checkmark$ & - & - & $\begin{array}{l}\text { - } \sim 1 \text { nm spatial } \\
\text { resolution } \\
\text { - Can be coupled to } \\
\text { spectroscopic tools }\end{array}$ & $\begin{array}{l}\text { - } \text { Inflicts beam } \\
\text { damage } \\
\text { - } \text { Requires } \\
\text { samples } \lesssim 100 \mathrm{~nm} \\
\text { thick }\end{array}$ & $\begin{array}{l}\mathrm{S} 20, \mathrm{~S} 21 \\
\mathrm{~S} 22, \mathrm{~S} 23 \\
\mathrm{~S} 24, \mathrm{~S} 25 \\
\mathrm{~S} 26\end{array}$ \\
\hline $\begin{array}{c}\text { Second } \\
\text { harmonic } \\
\text { generation } \\
\text { microscopy } \\
\end{array}$ & $\checkmark$ & - & - & - & $\begin{array}{l}\text { - Non-destructive } \\
\text { - Limit of detection } \\
\text { is superior to } \\
\text { optical microscopy }\end{array}$ & $\begin{array}{l}\text { - Only detect chiral } \\
\text { drug crystals } \\
\text { - Does not evaluate } \\
\text { composition }\end{array}$ & $\begin{array}{l}\text { S27, S28, } \\
\text { S29, S30, } \\
\text { S31 }\end{array}$ \\
\hline $\begin{array}{l}\text { Confocal } \\
\text { fluorescence } \\
\text { microscopy }\end{array}$ & - & $\checkmark$ & - & - & $\begin{array}{l}\text { - Non-destructive } \\
\text { - Can achieve in situ } \\
\text { observations }\end{array}$ & $\begin{array}{l}\text { - Resolution is } \\
\text { diffraction limited } \\
\text { - Requires selective } \\
\text { fluorophore }\end{array}$ & $\begin{array}{l}\text { S32, S33, } \\
\text { S34, S35, } \\
\text { S36, S37, } \\
\text { S38, S39, } \\
\text { S40 }\end{array}$ \\
\hline $\begin{array}{l}\text { Atomic force } \\
\text { microscopy }\end{array}$ & $\checkmark$ & $\checkmark$ & - & - & $\begin{array}{l}\text { - Non-destructive } \\
-\sim 1 \mathrm{~nm} \text { spatial } \\
\text { resolution }\end{array}$ & $\begin{array}{l}\text { - Only probes } \\
\text { samples surface }\end{array}$ & $\begin{array}{l}\text { S23, S32, } \\
\text { S41, S42, } \\
\text { S43, S44 }\end{array}$ \\
\hline
\end{tabular}

${ }^{\#}$ CRY is ability to detect for drug crystallinity, PS is ability to detect for polymer/drug phase separation, I is ability to probe polymer/drug interactions, and $\mathbf{M}$ is ability to probe molecular mobility. 


\section{References}

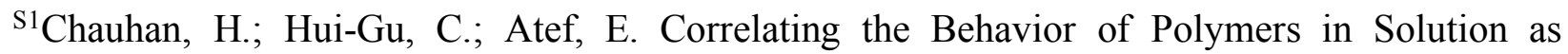
Precipitation Inhibitor to Its Amorphous Stabilization Ability in Solid Dispersions. J. Pharm. Sci. 2013, 102, 1924-1935.

${ }^{\text {S2} W e g i e l, ~ L . ~ A . ; ~ M a u e r, ~ L . ~ J . ; ~ E d g a r, ~ K . ~ J . ; ~ T a y l o r, ~ L . ~ S . ~ M i d-I n f r a r e d ~ S p e c t r o s c o p y ~ a s ~ a ~ P o l y m e r ~}$ Selection Tool for Formulating Amorphous Solid Dispersions. J. Pharm. Pharmacol. 2014, 66, $244-255$.

${ }^{3}$ Ting, J. M.; Navale, T. S.; Bates, F. S.; Reineke, T. M. Design of Tunable Multicomponent Polymers as Modular Vehicles To Solubilize Highly Lipophilic Drugs. Macromolecules 2014, 47, 6554-6565.

${ }^{\text {S4} R a h m a n, ~ Z . ; ~ S i d d i q u i, ~ A . ; ~ B y k a d i, ~ S . ; ~ K h a n, ~ M . ~ A . ~ N e a r-I n f r a r e d ~ a n d ~ F o u r i e r ~ T r a n s f o r m ~ I n f r a r e d ~}$ Chemometric Methods for the Quantification of Crystalline Tacrolimus from Sustained-Release Amorphous Solid Dispersion. J. Pharm. Sci. 2014, 103, 2376-2385.

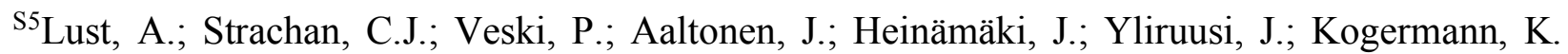
Amorphous solid dispersions of piroxicam and Soluplus ${ }^{\circledR}$ : Qualitative and quantitative analysis of piroxicam recrystallization during storage. Int. J. Pharm. 2015, 486, 306-314.

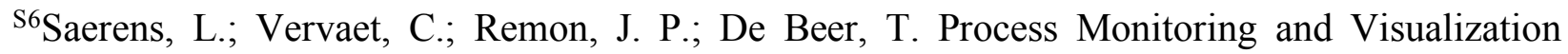
Solutions for Hot-Melt Extrusion: A Review. J. Pharm. Pharmacol. 2014, 66, 180-203.

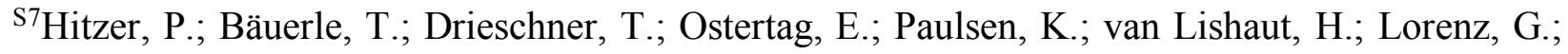
Rebner, K. Process Analytical Techniques for Hot-Melt Extrusion and Their Application to Amorphous Solid Dispersions. Anal. Bioanal. Chem. 2017, 409, 4321-4333.

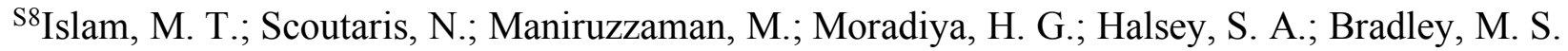
A.; Chowdhry, B. Z.; Snowden, M. J.; Douroumis, D. Implementation of Transmission NIR as a PAT Tool for Monitoring Drug Transformation during HME Processing. Eur. J. Pharm. Biopharm. 2015, 96, 106-116.

${ }^{\text {S9} K e r a t i c h e w a n u n, ~ S . ; ~ Y o s h i h a s h i, ~ Y . ; ~ S u t a n t h a v i b u l, ~ N . ; ~ T e r a d a, ~ K . ; ~ C h a t c h a w a l s a i s i n, ~ J . ~ A n ~}$ Investigation of Nifedipine Miscibility in Solid Dispersions Using Raman Spectroscopy. Pharm. Res. 2015, 32, 2458-2473.

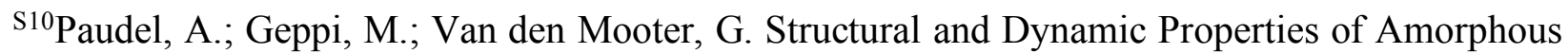
Solid Dispersions: The Role of Solid-State Nuclear Magnetic Resonance Spectroscopy and Relaxometry. J. Pharm. Sci. 2014, 103, 2635-2662.

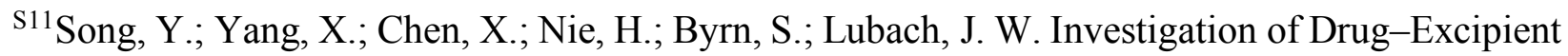
Interactions in Lapatinib Amorphous Solid Dispersions Using Solid-State NMR Spectroscopy. Mol. Pharm. 2015, 12, 857-866. 
S12Yuan, X.; Sperger, D.; Munson, E. J. Investigating Miscibility and Molecular Mobility of Nifedipine-PVP Amorphous Solid Dispersions Using Solid-State NMR Spectroscopy. Mol. Pharm. 2014, 11, 329-337.

${ }^{\mathrm{S} 13}$ Stueber, D.; Jehle, S. Quantitative Component Analysis of Solid Mixtures by Analyzing Time Domain ${ }^{1} \mathrm{H}$ and ${ }^{19} \mathrm{~F}_{1}$ Saturation Recovery Curves (qSRC). J. Pharm. Sci. 2017, 106, 1828-1838.

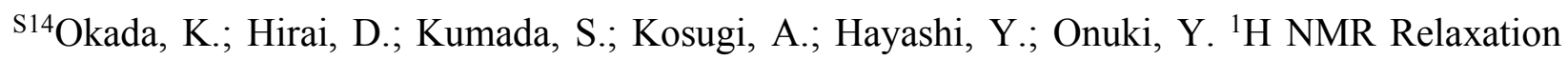
Study to Evaluate the Crystalline State of Active Pharmaceutical Ingredients Containing Solid Dosage Forms Using Time Domain NMR. J. Pharm. Sci. 2019, 108, 451-456.

${ }^{\mathrm{S} 15}$ Mehta, M.; Suryanarayanan, R. Accelerated Physical Stability Testing of Amorphous Dispersions. Mol. Pharm. 2016, 13, 2661-2666.

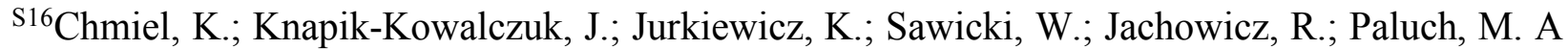
New Method To Identify Physically Stable Concentration of Amorphous Solid Dispersions (I): Case of Flutamide + Kollidon VA64. Mol. Pharm. 2017, 14, 3370-3380.

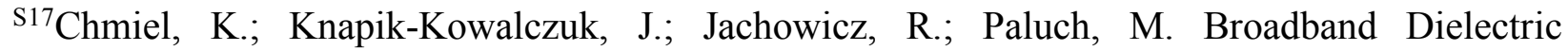
Spectroscopy as an Experimental Alternative To Calorimetric Determination of the Solubility of Drugs into Polymer Matrix: Case of Flutamide and Various Polymeric Matrixes. Eur. J. Pharm. Biopharm. 2019, 136, 231-239.

${ }^{\text {S18}}$ Singh, A.; Bharati, A.; Frederiks, P.; Verkinderen, O.; Goderis, B.; Cardinaels, R.; Moldenaers, P.; Van Humbeeck, J.; Van den Mooter, G. Effect of Compression on the Molecular Arrangement of Itraconazole-Soluplus Solid Dispersions: Induction of Liquid Crystals or Exacerbation of Phase Separation? Mol. Pharm. 2016, 13, 1879-1893.

${ }^{\text {S19} S c h a m m e ́, ~ B . ; ~ C o u v r a t, ~ N . ; ~ T o g n e t t i, ~ V . ; ~ D e l b r e i l h, ~ L . ; ~ D u p r a y, ~ V . ; ~ D a r g e n t, ~ E ́ . ; ~ C o q u e r e l, ~ G . ~}$ Investigation of Drug-Excipient Interactions in Biclotymol Amorphous Solid Dispersions. Mol. Pharm. 2018, 15, 1112-1125.

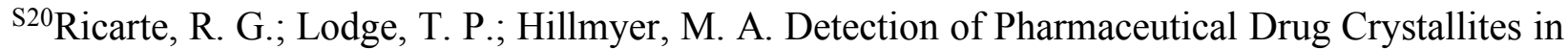
Solid Dispersions by Transmission Electron Microscopy. Mol. Pharm. 2015, 12, 983-990.

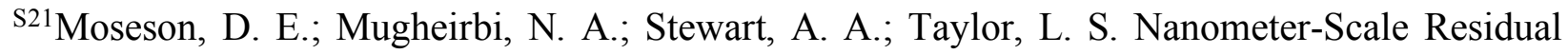
Crystals in a Hot Melt Extruded Amorphous Solid Dispersion: Characterization by Transmission Electron Microscopy. Cryst. Growth Des. 2018, 18, 7633-7640.

${ }^{2} 22$ ' ari, M.; Cattle, J.; Hondow, N.; Brydson, R.; Brown, A. Low Dose Scanning Transmission Electron Microscopy of Organic Crystals by Scanning Moiré Fringes. Micron 2019, 120, 1-9.

${ }^{\mathrm{S} 23} \mathrm{Li}, \mathrm{N}$.; Gilpin, C. J.; Taylor, L. S. Understanding the Impact of Water on the Miscibility and Microstructure of Amorphous Solid Dispersions: An AFM-LCR and TEM-EDX Study. Mol. Pharm. 2017, 14, 1691-1705. 


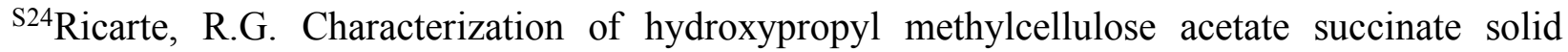
dispersions in the solid-state and during dissolution. Ph.D. Dissertation, University of Minnesota, Minneapolis, MN, 2016.

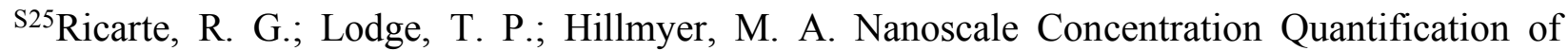
Pharmaceutical Actives in Amorphous Polymer Matrices by Electron Energy-Loss Spectroscopy. Langmuir 2016, 32, 7411-7419.

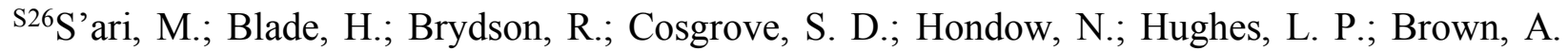
Toward Developing a Predictive Approach To Assess Electron Beam Instability during Transmission Electron Microscopy of Drug Molecules. Mol. Pharm. 2018, 15, 5114-5123.

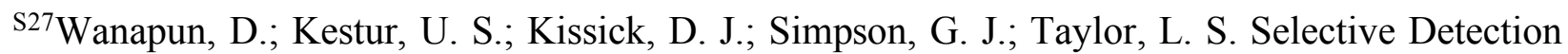
and Quantitation of Organic Molecule Crystallization by Second Harmonic Generation Microscopy. Anal. Chem. 2010, 82, 5425-5432.

${ }^{\text {S28}}$ Kestur, U. S.; Wanapun, D.; Toth, S. J.; Wegiel, L. A.; Simpson, G. J.; Taylor, L. S. Nonlinear Optical Imaging for Sensitive Detection of Crystals in Bulk Amorphous Powders. J. Pharm. Sci. 2012, 101, 4201-4213.

${ }^{\text {S29}}$ Toth, S. J.; Madden, J. T.; Taylor, L. S.; Marsac, P.; Simpson, G. J. Selective Imaging of Active Pharmaceutical Ingredients in Powdered Blends with Common Excipients Utilizing Two-Photon Excited Ultraviolet-Fluorescence and Ultraviolet-Second Order Nonlinear Optical Imaging of Chiral Crystals. Anal. Chem. 2012, 84, 5869-5875.

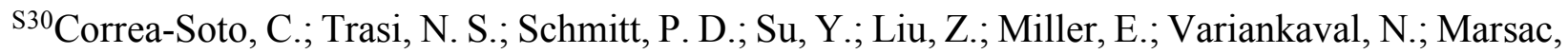
P. J.; Simpson, G. J.; Taylor, L. S. Second Harmonic Generation Microscopy as a Tool for the Early Detection of Crystallization in Spray Dried Dispersions. J. Pharm. Biomed. Anal. 2017, 146, 86-95.

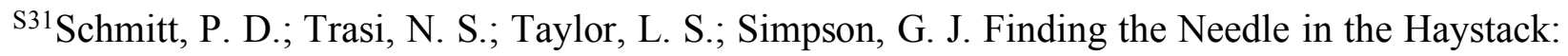
Characterization of Trace Crystallinity in a Commercial Formulation of Paclitaxel Protein-Bound Particles by Raman Spectroscopy Enabled by Second Harmonic Generation Microscopy. Mol. Pharm. 2015, 12, 2378-2383.

${ }^{332}$ Purohit, H. S.; Taylor, L. S. Miscibility of Itraconazole-Hydroxypropyl Methylcellulose Blends: Insights with High Resolution Analytical Methodologies. Mol. Pharm. 2015, 12, $4542-4553$.

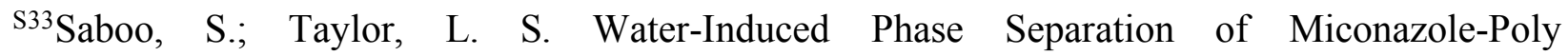
(Vinylpyrrolidone-Co-Vinyl Acetate) Amorphous Solid Dispersions: Insights with Confocal Fluorescence Microscopy. Int. J. Pharm. 2017, 529, 654-666.

${ }^{34}$ Purohit, H. S.; Taylor, L. S. Phase Behavior of Ritonavir Amorphous Solid Dispersions during Hydration and Dissolution. Pharm. Res. 2017, 34, 2842-2861. 
${ }^{535}$ Tian, B.; Tang, X.; Taylor, L. S. Investigating the Correlation between Miscibility and Physical Stability of Amorphous Solid Dispersions Using Fluorescence-Based Techniques. Mol. Pharm. 2016, 13, 3988-4000.

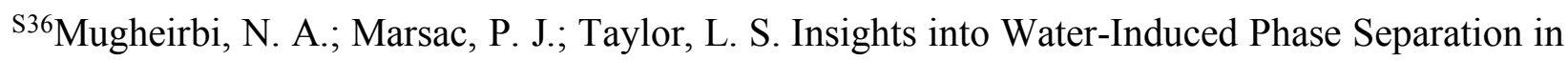
Itraconazole-Hydroxypropylmethyl Cellulose Spin Coated and Spray Dried Dispersions. Mol. Pharm. 2017, 14, 4387-4402.

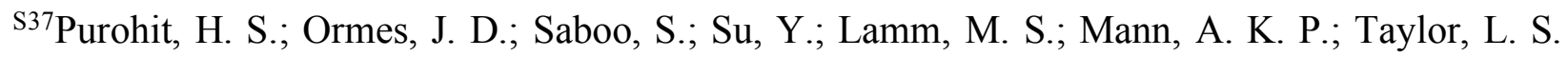
Insights into Nano- and Micron-Scale Phase Separation in Amorphous Solid Dispersions Using Fluorescence-Based Techniques in Combination with Solid State Nuclear Magnetic Resonance Spectroscopy. Pharm. Res. 2017, 34, 1364-1377.

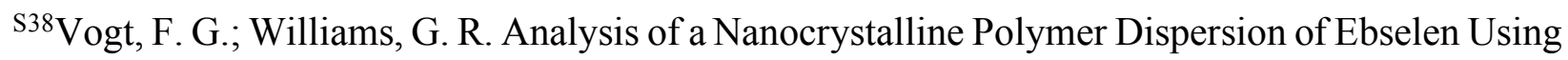
Solid-State NMR, Raman Microscopy, and Powder X-Ray Diffraction. Pharm. Res. 2012, 29, 1866-1881.

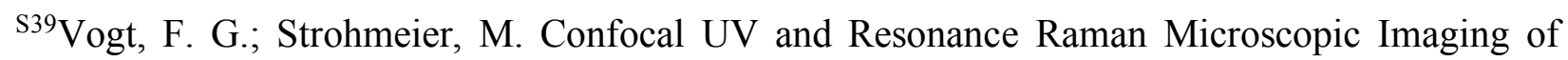
Pharmaceutical Products. Mol. Pharm. 2013, 10, 4216-4228.

${ }^{\mathrm{S} 40}$ Smith, G. P. S.; McGoverin, C. M.; Fraser, S. J.; Gordon, K. C. Raman Imaging of Drug Delivery Systems. Adv. Drug Deliv. Rev. 2015, 89, 21-41.

${ }^{\mathrm{S} 41}$ Van Eerdenbrugh, B.; Lo, M.; Kjoller, K.; Marcott, C.; Taylor, L. S. Nanoscale Mid-Infrared Imaging of Phase Separation in a Drug-Polymer Blend. J. Pharm. Sci. 2012, 101, 2066-2073.

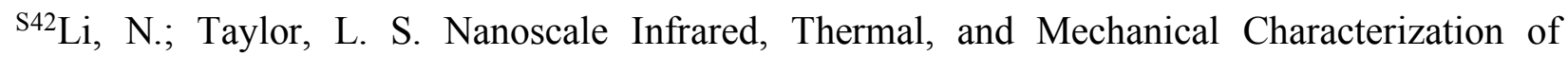
Telaprevir-Polymer Miscibility in Amorphous Solid Dispersions Prepared by Solvent Evaporation. Mol. Pharm. 2016, 13, 1123-1136.

${ }^{\mathrm{S} 43}$ Van Eerdenbrugh, B.; Lo, M.; Kjoller, K.; Marcott, C.; Taylor, L. S. Nanoscale Mid-Infrared Evaluation of the Miscibility Behavior of Blends of Dextran or Maltodextrin with Poly(vinylpyrrolidone). Mol. Pharm. 2012, 9, 1459-1469.

${ }^{444}$ Harrison, A. J.; Bilgili, E. A.; Beaudoin, S. P.; Taylor, L. S. Atomic Force Microscope Infrared Spectroscopy of Griseofulvin Nanocrystals. Anal. Chem. 2013, 85, 11449-11455. 